\title{
BAMBOO SHOOTS: ASIAN MIGRATION, TRADE AND BUSINESS NETWORKS IN SOUTH AFRICA
}

\author{
E. Kerby*
}

\begin{abstract}
Interconnected business and trade routes, or "bamboo networks" I have long been recognised as engines of growth in Asia. However, as Asian migration expands to Africa, what are their impact? This paper examines the links between trade flows and Taiwanese migration in South Africa from 1975 to 1995 . Constructing a bilateral trade series from novel declassified migration and trade data, two aspects of the change in trade are quantified: Firstly, how did international trade change during sanctions, vis-à-vis South Africa and its largest OECD trading partners? Secondly, using migration data, I examine the extent to which the 1975 immigration of Taiwanese investors to South Africa could have increased and diversified trade between the two countries through their investment. Three years after the lifting of sanctions, the share of South African exports to Taiwan was both greater, but importantly more diversified in the sectors in which migrants invested. Using archival accounts, I discuss the possible processes through which these changes to trade could have occurred. Known as the migrant-trade effect, the results suggest that Taiwanese entrepreneurs increased trade by forming business networks and supply chains linking them to Asian markets.
\end{abstract}

\footnotetext{
*Department of Economics, Stellenbosch University and LEAP. Private Bag X1, Matieland, 7602, South Africa.

Email: EdKerby@sun.ac.za

The author would like to thank Leigh Gardner, Waldo Krugell, Dieter von Fintel, Neil Rankin, Marianne Matthee and an anonymous referee for valuable input. In addition, seminar participants at LEAP Stellenbosch, LSE Economic History, NWU Trade Seminar and participants at the XVII World Economic History Congress (Kyoto) also provided insightful comments.
} 
"Using their vast trading networks; businessmen, industrialists and technologists of Chinese extraction are playing an increasingly constructive role in the development of a modern South Africa." 1

Minister K.T. Li,

Taiwanese Minister of Finance and Minister without Portfolio. January 1980

\section{Introduction}

Starting in 1975, trade between South Africa and Taiwan substantially increased and then began diversifying following ethnic Chinese migration to special economic zones. This may have naturally occurred as "Isolated State Geo-Politics" took hold when South Africa faced international sanctions and Taiwan was expelled from the United Nations, forcing the countries closer together. ${ }^{2}$ Although not causal, Figure 3 in Appendix A, demonstrates how the migration to South Africa may have been accompanied by an increase in bilateral trade between South Africa and Asia.

Using a novel dataset, I first benchmark the interdependence of South Africa's trade, relative to several of its larger, former 'colonial' and now OECD trading partners and then the subsequent growth with Taiwan. ${ }^{3}$ Second, using new migration data, I examine the extent to which the immigration of Taiwanese investors increased and but also diversified trade between the two countries. Finally, using archival accounts, I discuss the possible processes through which these changes occurred. I conclude that network linkages helped Taiwanese investors overcome informal barriers to trade, and were thus able to leverage existing business links, in turn, diversifying South Africa's exports. Export diversity continued after sanctions and the special economic zones were terminated.

This work makes a contribution in two ways: First, no prior research has been able to extract data delving into the possible causes for this shift in trade during apartheid. In one related study, Garner (1994) noted how they "were unable to ascertain whether the change reflected the activity of Taiwanese-owned firms, or switching activity from other trade partners, specifically Japan." ${ }^{4}$ At the time, Garner questioned whether he

\footnotetext{
${ }^{1}$ Minister K.T. Li notes in a parliamentary speech to South Africa that Taiwanese entrepreneurs have the advantage of "vast networks to expand trade which can be very constructive in manufacturing development." Quote excerpted from a 1980 newspaper article in the New China Times.

${ }^{2}$ Both countries were on the periphery of geopolitics. South Africa was a pariah because of its racist policies, while Taiwan lost international recognition as China in the United Nations. Geldenhuys (1991) uses this phrase as the title of his book "Isolated States: a comparative analysis" in which he compares the trade and geo-political strategies of ROC, RSA, Chile \& Israel in the 1980s.

${ }^{3}$ Sample Country Set: UK, Germany, France, United States, Japan, Taiwan, Hong Kong.

${ }^{4}$ Garner (1994, p. iii)
} 
change in bilateral trade reflected the activity of Taiwanese-owned firms. ${ }^{5}$ As such the combination of new archival trade and migration statistics can possibly provide an answer to this question in South Africa's apartheid economic history. Second, Taiwanese migrant trade networks were a unique phenomenon in South Africa. Taiwanese co-ethnic networks were easy to identify as South Africa had previously only a very small Chinese population before 1975 and limited bilateral trade. As such, South Africa is well placed as a case study of how Asian foreign investment and mass migration are interlinked with co-ethnic networks and the growth in export trade.

An international body of scholarship on migration, trade and investment has examined this effect in other markets. For example, Rauch and Casella (2001) found that ethnic Asian business networks had a significant impact on the volume of trade across North American borders. By enabling traders to overcome informational trade barriers, these migrant networks matched opportunities in international markets. Very little is known, however, about how Taiwanese investment may have had an impact on South Africa's exports, and to what degree diversification was driven by migration. In addition, a vast empirical literature shows the contribution of export diversification to economic growth, which is especially beneficial to developing countries in Africa. Gutiérrez de Piñeres and Ferrantino (1997) explain that the progression from 'traditional' to 'nontraditional' exports is an important component of export-led growth. ${ }^{6}$ A varied export production structure which includes new, but also higher value products enables positive manufacturing spillovers, making countries less susceptible to commodity shocks. ${ }^{7}$ South Africa, however, struggled to develop export-led manufacturing with commodities crowding out consumer goods and the continued failure of import substitution. ${ }^{8}$

Historically, business networks have been fundamental in the development of trade. Notable authors such as Greif (1994) and Gould (1994) have shown that informal and formal business networks play an increasing role in economic activities, providing alternatives to organised markets. Buyers and sellers establish personal links, and conduct trade on a bilateral basis, expanding international trade through a greater knowledge of local market preferences and ensuring contract enforcement. This has been a growing topic in economic history with Weidenbaum and Hughes (1996) showing how expatriate Chinese entrepreneurs, using the 'bamboo network',

\footnotetext{
${ }^{5}$ Garner (1994, p. 6) notes that without granular trade data (SIC) or country-specific volumes of trade, this research merely conjectured whether the reorientation was a result of the Taiwanese firms.

${ }^{6}$ South Africa, and Africa in general terms export commodities. As such, Gutiérrez de Piñeres \& Ferrantino (1997, p. 376) note that 'non-traditional' industries are presumed to be in manufacturing.

${ }^{7}$ Reis \& Farole (2012, p. 11 - 28)

${ }^{8}$ Moll (1991, p. 283) explains that the export of mining machinery did not take place. Dietz (1992, p. 236) noted that the inability to develop a capital goods sector meant that once mining declined and sanctions took hold very little new investment occurred in South African manufacturing.
} 
created a trade superpower in Asia. ${ }^{9}$ These connections improved communication, knowledge, and the transfer of capital, especially in regions where the businesses may be in the minority and rule of law remain undeveloped, such as apartheid South Africa. More recently Vézina and Parsons (2016) used the Vietnamese boat people in the United States as a natural experiment, showing how these immigrants fostered international trade between the US and Asia by reducing trade costs and increasing exports. However Bräutigam (2003) notes that very limited research has been done on [co-ethnic] Chinese business networks in Africa. As such, my case studies of Taiwanese migration and the growth in trade with Asia are the first examples of 'bamboo shoots' which have established trade networks in South Africa.

The remainder of the paper unfolds as follows: Section 2 provides the historical and theoretical context to trade and migration in South Africa. Section 3 details the underlying data collection and research methodology. Section 4 analyses the assimilated bilateral trade data. Section 5 is a discussion on the evolution of trade and the role of migrant trade and business networks.

\section{$2 \quad$ Historical context}

South Africa's economy was traditionally characterised by its openness with a long history of trade and migration. Throughout the twentieth century South Africa's trade with its former colonial and western OECD partners had played a crucial role in the growth of the economy. ${ }^{10}$ In exchange for the export of gold, diamonds and an assortment of minerals, South Africa imported capital equipment and technology. ${ }^{11}$ From 1925 to 1973, the government pursued an active policy of import substitution to stimulate domestic manufacturing with state investment in key sectors. ${ }^{12}$ Edwards and Lawrence (2008) note how this trade protection had seriously impeded both exports and imports.

By 1970s the economy became increasingly sluggish with export trade in minerals and manufacturing declining further. ${ }^{13}$ Sanctions then began to take their toll in 1974, as it became increasingly difficult to raise offshore financing for both the private and public sectors. ${ }^{14}$ First Switzerland imposed a cap on credit extensions to

\footnotetext{
${ }^{9}$ The bamboo network is traced to the 16th century, and can be thought of as a Chinese Commonwealth. The concept has been used to describe how businesses which are operated by overseas Chinese act as conduits for trade which are then guided by family ties and personal relationships as opposed to formal relationships.

${ }^{10}$ A large proportion (64\% in 1979) of South Africa's bilateral trade was with OECD countries - mainly Western Europe, North America and Japan.

${ }^{11}$ Feinstein (2005)

${ }^{12}$ ISKOR (iron \& steel), ESKOM (electricity), SAPPI (forestry \& paper) and SASOL (fuels \& Chemicals)

${ }^{13}$ Jones (2002, p. 115) explains that the decline of manufacturing in the 1970s was closely related to the output and price of gold.

${ }^{14}$ United Nations Centre Against Apartheid (1978) United Nations Centre Against International Conference on
} 
South Africa. ${ }^{15}$ This was followed by Midland Bank in 1975, halting loans to the government or its agencies, which intensified in 1978 to all counterparties with any South African activity. Havemann (2014) notes that the most ominous gestures came in 1978 when a number of banks in the United States terminated all loans. Compounding this was an IMF prohibition of loans in 1978. As a result, Western investors, fearful of growing financial and political instability began to withdraw funds or to move it into short-term rather than long-term investments.

In 1975 some significant changes to South Africa's trade relationships began to occur in individual rankings; in response to sanctions but also through a reorientation of trading partners. Both Britain and Japan declined, with Taiwan becoming the fastest growing trading partner to South Africa during the period. ${ }^{16}$ Moreover, South Africa had historically traded homogenous, reference-price products, such as mineral ores in global markets, while failing to develop competitive manufacturing exports. Following the signing of ROC - RSA trade treaties in 1976, migration grew rapidly. As part of a "chain migration"17, Hart (2002b) found this that large cohort of Taiwanese investors were deeply connected to their homeland and sites across East Asia.

For example, clusters of Taiwanese-owned factories were established in a select set of the special economic zones (RIDP zones) producing manufactured goods for exports. These migrants brought with them product knowledge of foreign (Asian) markets, new labour-intensive production methods, and trading networks. Urban trading companies sprang up in major metropolitan areas to meet the raw input demands of Taiwanese firms, and to support cross-border transactions.

The ethnic Chinese community in South Africa was a very small, silent minority prior to1975. ${ }^{18}$ This, however, began to change with the influx of Taiwanese investment. South Africa was in the process of reviving the domestically unpopular decentralisation programme during the late 1970s, which sought to shift labourintensive industries to the most rural African homelands. The RIDP attracted the attention of small-scale Taiwanese export-oriented enterprises attempting to internationalise as a result of rising costs and competition on the island. ${ }^{19}$ In South

\footnotetext{
Sanctions Against South Africa, UNESCO House, Paris - first findings on trade embargo.

${ }^{15}$ Ovendon \& Cole (1989)

${ }^{16}$ Garner (1994, p. 7) could not determine if this was a result of Taiwanese foreign investment in the homeland RIDP zones.

${ }^{17}$ MacDonald \& MacDonald (1964) define this as a "movement in which prospective migrants learn of opportunities, are provided with transportation, and have initial accommodation and employment arranged by means of primary social relationships with previous migrants."

${ }^{18}$ Van der Watt \& Visser (2008)

${ }^{19}$ Pickles \& Woods (1989, p. 510)
} 
Africa, the Taiwanese foreign investors offered one of the only opportunities for black homelands to attract new industries to their zones. ${ }^{20}$ Seeking out Taiwanese investment (and immigration), successive marketing campaigns and trade missions were sent to Taiwan and Hong Kong in an attempt to attract capital to these RIDP zones. In doing so, South Africa revised its immigration laws relating to residence permits and multiple-entry visas for Taiwanese. The changes were aimed primarily at facilitating Taiwanese investment in the Republic. ${ }^{21}$

Demonstrating the immigration trend, Figure 7 in Appendix $\mathrm{C}$ graphically plots the waves of Taiwanese migrants to South Africa against the important diplomatic, political and industrial events. Three migration spikes corresponding to the recruitment drives and political events can be observed. The first wave (A) followed trade missions and changes by the KwaZulu-Natal Finance Corporation and Transkei Development Corporation (1978 - 1980), expediting visa registrations for Taiwanese enterprises. These were designed to "welcome Taiwanese industrialists and build networks of firm collaboration between the Development Corporation and foreign investors." 22

The second wave arrived after the announcement of the Good Hope RIDP incentives (B), which saw a deliberate effort to increase subsidies and attract foreign investment. The third and final large wave (C) followed the political changes in the Orange Free State province, namely the repeal of Act XXXIII, which had prevented Chinese from settling in the province. A marked decline in immigration (D) is seen from 1990 as RIDP subsidies were removed in 1992 and South Africa transitioned towards democracy in 1994. The Taiwanese population also declined due to emigration. Whether the termination of the incentives or diplomatic links account for this is debatable. $^{23}$

Although social acceptance among white South Africans towards the growing ethnic Chinese adapted during the1980s, a deep racial divide in business persisted. ${ }^{24}$ As a result "boundaries and borders, both real and metaphorical, related to various Chinese communities in southern Africa" 25 Park (2008) explains that because of their small numbers and variations in categorising Chinese, bureaucrats were often at a loss as to what to do with the few Chinese they encountered. ${ }^{26}$

\footnotetext{
${ }^{20}$ Pickles \& Woods (1989, p. 515) explains that virtually all of the investments were in the homelands.

${ }^{21}$ Pickles \& Woods (1989, p. 513)

${ }^{22}$ The Developer, 1979, issue 2, Mthata Archives.

${ }^{23}$ The 2001 census found that the population was estimated to be 10,000 in 2012 .

${ }^{24}$ Park (2008, p. 124)

${ }^{25}$ Park (2010, p. 457)

${ }^{26}$ Park (2008, p. 125) notes how "second and third generation Chinese South Africans attested to the confusion in the day-to-day implementation of apartheid laws affecting them."
} 
Tensions also formed between the Chinese South Africans and the newly arrived Taiwanese, ${ }^{27}$ while relations with the white business community remained limited to urban areas. Van der Watt and Visser (2008) found that the Chinese were commonly perceived to be a threat to the white small businessmen, and legal obstacles in the form of permits and restrictions were regularly put in their way. This was not a new impediment, as the original Chinese (Cantonese) and later Taiwanese communities in South Africa faced a long history of institutionalised discrimination. As a result, Taiwanese immigrants resorted to their existing transnational networks, which were important for trade and investment. ${ }^{28}$

\section{$3 \quad$ Data and methodology}

Compiling estimates from statistical measures in South Africa during this time was fraught with challenges of data availability and consistency in reporting. The changes to bilateral trade and foreign investment were shrouded in secrecy during sanctions. Once again Geldenhuys (1991) explained how South Africa's financial and statistical agencies stopped publishing trade statistics in 1986, remarking that "only a geographical breakdown of South Africa's international trade has been available for world zones, namely Africa, Europe, Americas, Asia and Oceania". ${ }^{29}$ To overcome these challenges, I have compiled a new dataset of South Africa's trade with it's largest traditional OECD partner from 1975, and then used new archival sources to reconstruct migration patterns.

\subsection{Trade data}

The restrictions on trade data resulted in a skewed, but hidden view of South Africa's bilateral trade relationships. Annemarie van der Walt, the head of archival trade statistics at the South African Revenue Services (SARS), ${ }^{30}$ noted in written communication, "prior to 1992 all statistical data held by this institution referring to trade between Chinese Taipei and South Africa is likely to be unreliable at best". 31 The reasons for this scarcity are manifold. Certain scholars have inferred that the 'under-reporting' was done in order to protect both the trading partner who sought to circumvent sanctions, or as a direct act of data secrecy by the Nationalist Government who were under severe external funding pressure. ${ }^{32}$ For example Kaempfer, Lehman

\footnotetext{
${ }^{27}$ Park (2010, p. 457 - 458)

${ }^{28}$ Hart (1996, p. 14) also demonstrated how the "original investors were joined by small, new firms established by their own former technicians [...] who began to subcontract to their former firms. Some of the older firms supplied credit to the new firms."

${ }^{29}$ Geldenhuys (1991, p. 267)

${ }^{30}$ Institution responsible for recording bilateral trade for the purpose of tax collection.

${ }^{31}$ Per email communication dated 11/04/2013.

${ }^{32}$ See Ovendon \& Cole (1989) for a synopsis on how SA circumvented sanctions.
} 
and Lowenberg (1987) explained that much of the trade history has been underreported with the "South African government permitting firms to withhold sensitive data from their financial reports [...] indicating that it will not enforce international trade practices, such as labelling the origin of goods. ${ }^{33}$ Furthermore, much of the data has been overlooked due to restricted access and the sheer labour intensity of reconstructing bilateral trade series from diffuse archival documents.

Using declassified trade statistics and a triangulation of two further published sources, this paper assembles a new, more complete bilateral trade data series for each of the twenty three reported Standard Industrial Classifications (SIC). The bulk of the new data (1984 - 1992) was transcribed from new archival sources. From 1975 until 1985 the bilateral data is compiled using the official international trade statistics series. ${ }^{34}$ These official records captured trade between South Africa and all its trading partners. The trade data was segmented according the Sections of the Harmonised System for 23 product categories..$^{35}$ Between 1986 and 1992 the Department of Trade stopped publishing trade statistics at the country level altogether. Garner (1994) noted that researchers had to turn to other sources as a result of a data embargo, and doubted the accuracy of any publicly available data. This limitation has impacted migration and trade research, as it was during these rigid years of sanctions that growth in Taiwanese trade could have accounted for the reorientation. To estimate the years 1986 - 1992, Garner used an alternative series. These sources included revised estimates from the UN, IMF and OECD adjusting it with data in the Sanction Report produced by Hanlon and Omond (1987). However Garner noted that the IMF Direction of Trade Statistics were "a misleading set of figures on partner countries with South Africa. [...] They were calculated by scaling up or down figures from the base year in 1985 across all countries by a uniform percentage" 36 Nonetheless, the IMF's interpolated Direction of Trade Statistics database was useful as it recorded aggregate regional data from where a baseline for the new data could be established and contrasted.

To overcome the access limitations and data constraints imposed during the years of sanctions, I have recreated the bilateral trade series with additional, declassified trade statistics from the Department of Trade and Industry. These were reported in annual

\footnotetext{
${ }^{33}$ Kaempfer, Lehman \& Lowenberg (1987, p. 276)

${ }^{34}$ Hardcopy trade statistics were digitised from original archival records held at the National Treasury, the National Archive in Pretoria and the University of Cape Town government publications library.

${ }^{35}$ The Standard Industrial Classification (SIC) is a system for classifying industries by a four-digit code. South Africa used this system until 1988, after which it shifted to the Harmonised Commodity Description and Coding System, also known as the Harmonised System (HS) of tariff nomenclature developed and maintained by the World Customs Organisation (WCO). SIC codes have been mapped to HS codes using the standard 4 digit methodology to keep consistency across all years.

${ }^{36}$ Garner (1994, p. ii)
} 
returns held at the Parliamentary Library in Cape Town. Although these statistics should therefore have created a complete series, I nevertheless found it necessary to validate their accuracy. As such these are further supplemented with regional and national estimates reported in Garner to compare the official reports with IMF partner country data and South African data. Trade data from 1992 until 1995 was obtained from the South African Revenue Services (SARS) balance of trade database. ${ }^{37}$ This contained monthly and annual trade flows with all South Africa's trading partners. 1995 is chosen as the end date for the study, as it is 4 years after the US Comprehensive Anti-Apartheid Act ${ }^{38}$ was repealed and EU Sanctions ${ }^{39}$ were lifted. This provides sufficient post sanctions data to examine whether the Taiwanese diversification in exports was merely a reaction to isolationisms or a permanent feature of the export trade partnership. ${ }^{40}$

\subsection{Migration data}

In addition to trade data limitations, recent migration studies have also suffered from data availability. For example Stapleton (2015) explained how empirical research into migration in South Africa is conspicuous in its absence. Empirical migration studies require longitudinal data that can track individuals across time. Therefore data limitations, especially during late apartheid have restricted any migration studies.

The Department of Internal Affairs recorded the total number of permanent residents entering and leaving the country each month. However South Africa's data collection was further clouded by racial restrictions on migration and the balkanisation of homelands, which collected their own statistics. In the aggregated national statistics, only developed countries were recorded, while those in Africa and Asia, apart from Japan, were simply grouped at the regional level. As such, official Department of Internal Affairs migration statistics could not be used to quantify Taiwanese immigration. In fact Taiwanese immigration was never recorded in the Internal Affairs statistics, which was curious, as my research shows that they were the largest cohort of immigrants during the 1980 - 1990 period (highlighted in Appendix C, Figure 5 on page 29). ${ }^{41}$

Conservative estimates of Taiwanese migration and population series were

\footnotetext{
${ }^{37}$ Head of Data Archives, Annemarie van der Walt, SARS email

38 st of July, 1991

${ }^{39} 15$ th of April, 1991

${ }^{40}$ The sample of bilateral trade data represents $68 \%$ of South Africa's total 1975 bilateral trade. By 1995 the selected countries had declined to $59 \%$ of South Africa's total foreign trade but still represents a significant sample over the 20 years of analysis and is therefore sufficient for purpose of my trade and migration study.

${ }^{41}$ Although South Africa had a high level of sub-Saharan migration to the mines (i.e. Mozambique, Malawi and Lesotho) these are excluded from my statement. These were circular migratory patterns with no permanent settlement in South Africa.
} 
assembled from the Board for the Decentralisation business license applications (National Archive, Pretoria, RSA). ${ }^{42}$ Using the business license applications, Table 1 below shows the total number of immigrants in each of the years. However the exact quantum of Taiwanese citizens residing in South Africa is difficult to gauge and remains contentious. Examination of official emigration and immigration statistics is challenging as the South African government only recorded race "Asian" for all immigrants from Asia between 1950 and 1990. A total of 100,000 Taiwanese individuals were estimated to have immigrated and emigrated between the two countries. However Grimm et al. (2014) noted that at the height of this relationship, 50,000 Taiwanese people resided permanently in South Africa. This estimation proves the most accurate and is corroborated by similar accounts as no official RSA statistics have been located to the full extent of Taiwanese migration.

The upper bound of Taiwanese immigration estimated by Grimm et al. is useful, however an annual migration series is required for this study. To gain a measure of the annual inbound flow of Taiwanese immigrants I therefore had to turn to the Board for the Decentralisation of Industries (BDI) as a proxy, which granted business license applications. Administering the 8 development regions, the BDI was the overarching statutory body. The BDI recorded the country of origin and the number of immigrants that were accompanying the business licence application which are tabulated below.

Between 1980 and 1991, a total of 11,036 business licenses were granted across all eight of the RIDP zones. Further contextualising the Taiwanese immigration, I have also collected the total European immigration statistics from South Africa's former direct and indirect colonial partners as a benchmark. Although these are not necessary to the analysis, they are useful to contextualise the long-term effect of trade networks, market preferences and migration in South Africa. ${ }^{43}$ Appendix C Figure 5 tabulates total European immigration as a proxy for direct and indirect colonial trade ties against which to measure the Taiwanese case study.

\footnotetext{
${ }^{42} 1,036$ business licenses were granted to ROC companies over the period, however it appears that only $30 \%$ of those licenses were taken-up. This is consistent with the totals found by Pickles and Wood (1989) for the earlier period where they found only 91 of the 300 business licenses were taken up.

${ }^{43}$ Figure 5 in Appendix C shows annual European flows.
} 
Table 1: RIDP Business License Application (1980 - 1991) for the whole RIDP project number Taiwanese applicants (LHS).

\begin{tabular}{|c|c|c|c|c|c|c|c|}
\hline \multicolumn{8}{|c|}{ Business'License'Applications' } \\
\hline \multirow{2}{*}{$\begin{array}{l}\begin{array}{r}\text { Business' } \\
\text { Licenses' }\end{array} \\
" 1980 "\end{array}$} & \multirow{2}{*}{$\begin{array}{c}\begin{array}{c}\text { Total' } \\
\text { Approved' }\end{array} \\
" \\
680 "\end{array}$} & \multicolumn{2}{|c|}{$\begin{array}{c}\text { Established' } \\
\text { !No!!!!!!!!!!!!\%! } \\
\end{array}$} & \multirow{2}{*}{$\begin{array}{c}\text { ROC' }^{\prime} \\
\text { Approved' } \\
" \\
27 "\end{array}$} & \multicolumn{2}{|c|}{ 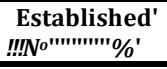 } & \multirow{2}{*}{$\begin{array}{c}\begin{array}{c}\text { Residence } \\
\text { Permits' }\end{array} \\
" \\
1,387 "\end{array}$} \\
\hline & & $247 "$ & $36 \% "$ & & $11 "$ & $40 \% "$ & \\
\hline 1981" & 798" & $355^{\prime \prime}$ & $44 \% "$ & $31 "$ & $14 "$ & $45 \% "$ & $4,067 "$ \\
\hline 1982/1983" & 777" & 384" & $49 \% "$ & $27 "$ & $20 "$ & 74\%" & $1,890 "$ \\
\hline 1983/1984" & $1,190 "$ & $578 "$ & $48 \% "$ & $17 "$ & $14 "$ & $82 \% "$ & 3,876" \\
\hline 1984/1985" & $1,216 "$ & $452 "$ & 37\%" & $29 "$ & $21 "$ & $72 \% "$ & $278 "$ \\
\hline 1985/1986" & $1,243^{\prime \prime}$ & NA" & $0 "$ & $27 "$ & $22 "$ & 81\%" & 490" \\
\hline 1986/1987" & $1,027^{\prime \prime}$ & NA" & $0^{\prime \prime}$ & $51 "$ & $42 "$ & $82 \% "$ & 7,907" \\
\hline 1987/1988" & $1,080^{\prime \prime}$ & NA" & $0 "$ & $55 "$ & $51 "$ & $92 \% "$ & $900 "$ \\
\hline 1988/1989" & $1,042 "$ & NA" & $0 "$ & 78" & 63" & $80 \% "$ & $876 "$ \\
\hline 1989/1990" & 893" & NA" & $0 "$ & 31" & $24 "$ & 77\%" & $20 "$ \\
\hline 1990/1991" & $\begin{array}{c}1,090 " \\
"\end{array}$ & $\begin{array}{c}470 " \\
\text { " }\end{array}$ & $\begin{array}{c}43 \% " \\
"\end{array}$ & $\begin{array}{c}19 " \\
"\end{array}$ & $\begin{array}{c}14 " \\
" ~\end{array}$ & $\begin{array}{c}73 \% " \\
\text { " }\end{array}$ & $\begin{array}{c}657 " \\
"\end{array}$ \\
\hline TOTAL' & $1,1036^{\prime}$ & $4,181^{\prime}$ & $37 \%$ & 382' & $296^{\prime}$ & 78\%' & $23,137^{\prime}$ \\
\hline
\end{tabular}

Note: The results show the difference between approved and established. (RHD) and the total number Taiwanese applicants (LHS). The results show the difference between approved and established.

Source: Board for the Decentralisation, business license applications (National Archive, Pretoria, RSA).

\subsection{Methodology}

The migrant-trade effect examines the degree to which exports shift from homogeneous to differentiated products following the inflow of migrants. Promoting bilateral trade, the effect operates through two channels. Firstly migrants reduce information costs, as the mechanism of matching and referral services is more important for differentiated exports such as manufactured goods, which require the provision of information regarding trading opportunities. Secondly, it improves contracting conditions as migrant networks had an impact on trade through community enforcement or sanctions that deterred opportunistic behaviour, and encouraged co-operation. This increased the potential for host countries with larger migrant populations to diversify and increase trade. Therefore could Taiwanese migrants have increased South Africa's export trade by means of matching sellers and improving contracting and thus making it more competitive?

Rauch and Casella (2001) first proposed this empirical trade-flow model to show how a network, formed by the overseas Chinese population, had a major trade- 
creating effect. Informal co-ethnic networks formed by migrants "like the Chinese trading network [...] and formal business networks such as the Japanese keiretsu have a significant impact on the volume of trade across borders." ${ }^{44}$ These networks had an economically positive impact on bilateral trade in differentiated rather than homogeneous products. ${ }^{45}$

Exploiting my new, more complete trade series, the following analysis examines three discrete elements of the changes to differentiated and homogenous bilateral trade with Asia, following Taiwanese migration.

1. First it quantifies the macro trends from1975, highlighting regional and country shifts, which underscored South Africa's trade partnerships in the 1980s. This provides the basis against which to measure OECD exports vis-à-vis Taiwanese.

2. Second it quantifies bilateral trade with Taiwan. Using the intensive and extensive margin of trade provides the basis for analysing the substitution effects during sanctions.

3. Finally, using the SIC codes, it categorises the change in South Africa's export trade with Taiwan, examining the degree to which exports shifted from homogeneous to differentiated products.

Each of these analysis questions build on one another. The last section then qualitatively discusses whether the emergence of trade networks account for any observed changes to Taiwanese exports.

\section{$4 \quad$ Analysis}

\subsection{Macro trends}

In 1975, South Africa was among the leading 25 trading nations in the west. ${ }^{46}$ Direct colonial ties with Britain, and indirect OECD ties with Germany, France and the United States accounted for much of the export trade. Imports from Germany, the US, Japan and Britain accounted for $63 \%$ of merchandise purchases in 1975, with the remainder widely and thinly spread. As such, South Africa's foreign trade has been concentrated with the leading OECD states. We would therefore expect these to persist in the export data going into the 1970s and 1980s.

\footnotetext{
${ }^{44}$ Rauch \& Casella (2001, p. 7)

${ }^{45}$ Rauch \& Trindade (2002) find that for trade between countries with ethnic Chinese population shares at the levels prevailing in Southeast Asia, the smallest estimated average increase in bilateral trade in differentiated products attributable to ethnic Chinese networks is nearly $60 \%$."

${ }^{46}$ Assuming South Africa could be considered a member of the western block (Geldenhuys, 1991, p. 345)
} 
It is important to note that trends in South Africa's exports emphasise the country's largest export earner, namely gold (Table 2). Exports were highly sensitive to changes in the price and production of gold. Over the 1970s and into the 1980s, the quantity of gold produced and exported declined. However in the 1980s, a sharp increase to $\$ 800$ an ounce witnessed a windfall in the exports.

Jones and Inggs (1994) notes how non-gold mineral exports increased in the 1970s with the development of new mines and transport infrastructure. This is clearly observed in Table 2. Furthermore non-gold minerals began to outstrip gold exports in 1976, superseding its importance, and thus diversifying exports further. This market diversification reduced South Africa's vulnerability to economic sanctions. For example, I found that that South Africa's largest mineral market (Japan) absorbed only $17.8 \%$ of South Africa's mineral exports. Geldenhuys (1991) notes that this partly explains why sanctions were not a crippling blow to the economy when Japan, and then the US, imposed import bans on South African commodities. A noticeable decline of trade was observed in exports to Britain. In 1984, Britain had dropped to 3rd place ${ }^{47}$ with the US and Japan surpassing UK exports.

Britain's entry into the European Economic Community partly explains this change, as South Africa no longer enjoyed preferential access as a former Commonwealth member. The US's imports from South Africa expanded strongly just before sanctions were imposed. However it appears that Japan's decline in export trade with South Africa wasn't as pronounced as prior research from Garner (1994) had speculated. Indeed there was a decline after 1985, but exports remained stable during the sanctions period. This would give credence to Geldenhuys (1991) who found that a "cloak of official secrecy" surrounded exports when Japan had not included "massive gold imports in their officially released figure". 48

\footnotetext{
${ }^{47} 4$ th place if Switzerland had been included in the sample, but as they mostly received gold exports (97\%), it was necessary to exclude the Swiss from the sample-country set.

${ }^{48}$ Geldenhuys (1991, p. 349)
} 
Table 2: Gold, Mineral and All Other Exports expressed as a Percentage of Total Exports for the Sample Group (1975 - 2000).

\begin{tabular}{|c|c|c|c|c|}
\hline \multicolumn{5}{|c|}{ Gold and Mineral Exports } \\
\hline & Gold Exports & Mineral Exports & Others Exports & Total \\
\hline 1975 & $30.8 \%$ & $19.8 \%$ & $49.4 \%$ & 100 \\
\hline 1976 & $24.0 \%$ & $29.6 \%$ & $46.4 \%$ & 100 \\
\hline 1977 & $29.1 \%$ & $31.9 \%$ & $39.1 \%$ & 100 \\
\hline 1978 & $21.2 \%$ & $29.3 \%$ & $49.5 \%$ & 100 \\
\hline 1979 & $19.1 \%$ & $35.5 \%$ & $45.4 \%$ & 100 \\
\hline 1980 & $25.4 \%$ & $29.5 \%$ & $45.1 \%$ & 100 \\
\hline 1981 & $17.5 \%$ & $35.2 \%$ & $47.3 \%$ & 100 \\
\hline 1982 & $15.8 \%$ & $36.6 \%$ & $47.5 \%$ & 100 \\
\hline 1983 & $18.5 \%$ & $35.6 \%$ & $45.9 \%$ & 100 \\
\hline 1984 & $11.0 \%$ & $41.3 \%$ & $47.7 \%$ & 100 \\
\hline 1985 & $10.9 \%$ & $41.7 \%$ & $47.4 \%$ & 100 \\
\hline 1986 & $24.2 \%$ & $31.9 \%$ & $43.9 \%$ & 100 \\
\hline 1987 & $19.9 \%$ & $34.3 \%$ & $45.8 \%$ & 100 \\
\hline 1988 & $20.1 \%$ & $30.9 \%$ & $49.0 \%$ & 100 \\
\hline 1989 & $20.3 \%$ & $29.1 \%$ & $50.6 \%$ & 100 \\
\hline 1990 & $20.4 \%$ & $27.0 \%$ & $52.5 \%$ & 100 \\
\hline 1991 & $24.9 \%$ & $35.0 \%$ & $40.1 \%$ & 100 \\
\hline 1992 & $24.9 \%$ & $35.0 \%$ & $40.1 \%$ & 100 \\
\hline 1993 & $26.1 \%$ & $34.3 \%$ & $39.6 \%$ & 100 \\
\hline 1994 & $30.0 \%$ & $27.8 \%$ & $42.2 \%$ & 100 \\
\hline 1995 & $29.8 \%$ & $29.6 \%$ & $40.6 \%$ & 100 \\
\hline
\end{tabular}

Source: Foreign Trade Statistics 1975 - 1985, Department of Trade and Industry, Garner (1994), IMD direction of trade statistics (1986 -1990). South African Revenue Services (1991 - 1995).

In 1975, South Africa's annual exports to Taiwan barely reached $\$ 100$ million. By 1984, South Africa's non-traditional Asian markets (Taiwan and Hong Kong) were becoming increasingly important for her exports. Figure 1 below clearly confirms the Garner (1994) theory that Taiwan was the fastest growing trade partner and can now be accurately estimated. It is against this backdrop that changes to Taiwanese trade is next explored.

\subsection{Bilateral trade with Taiwan}

While export trade diminished with South Africa's traditional partners, bilateral trade with Taiwan increased. In this section I therefore examine how exports changed by quantifying the extensive margin (volume over time) and the intensive margin (change in diversity). The growth in value (extensive margin), and the change in diversity (intensive margin) could be emblematic of greater connections and deeper markets as result of immigration. Although not causal, migration to South Africa highlights the potential relationship between the extensive and intensive margins. 


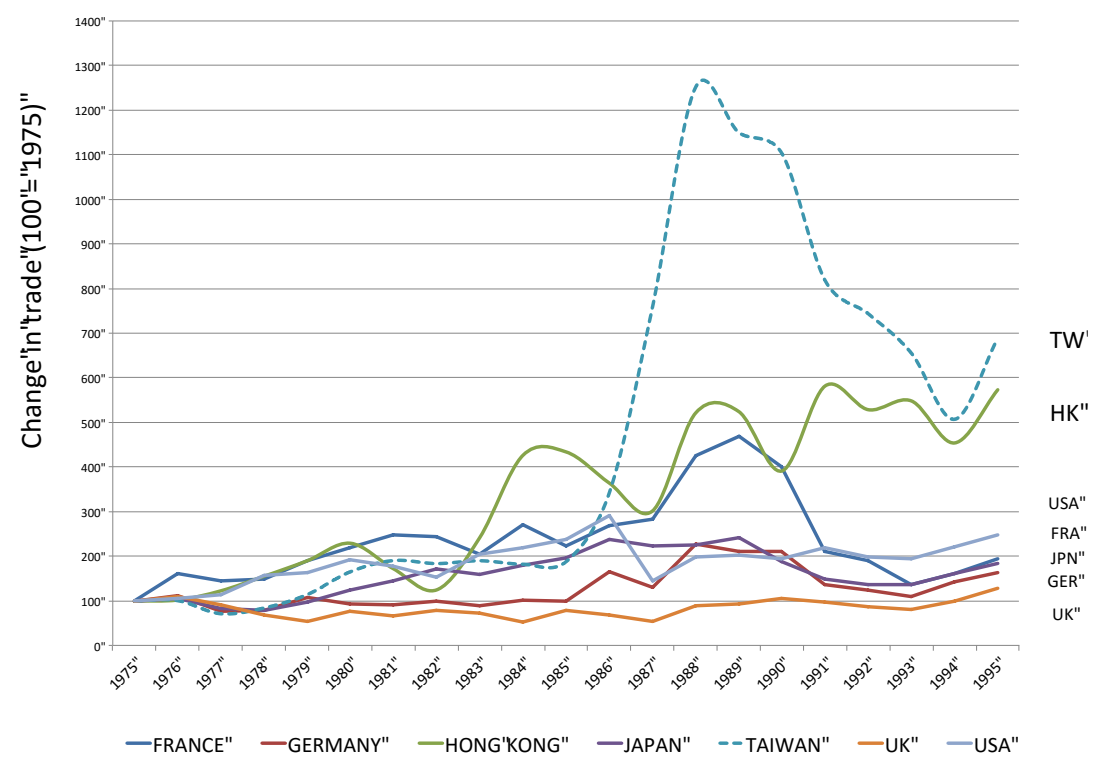

Figure 1: Percentage Change in Exports to Sample Countries, Nominal US \$ (1975 - 1995)

Source: Foreign Trade Statistics 1975 - 1985, Department of Trade and Industry, Garner (1994), IMD direction of trade statistics (1986 -1990). South African Revenue Services (1991 - 1995).

The volume of trade with Taiwan could have also have been skewed by the growth in mineral exports and the changing US \$ price of gold. However, to examine the possibility that this shift in trade occurred at both the extensive and intensive margin and not just because of minerals exports, the data is disaggregated into five main groups using the SIC code. These categories include Agriculture and Foods, Minerals, Consumers Goods, Capital Goods and Processed Chemicals. Confirming the hypothesis, Figure 2 below demonstrates the shift in export trade with South Africa, growing in all sectors. Before discussing the possible causes for these changes in the next section, two trends relating to the margin of trade can be identified. Firstly, there was continuous growth in exports of Minerals ${ }^{49}$ accelerating between 1986 1988, and again in 1990. This is representative of the extensive margin, i.e. where trade between countries already exists, we would expect this to continue and grow overtime. ${ }^{50}$

\footnotetext{
${ }^{49}$ Mineral SIC Grouping: 5, 14 \& 15 - See Appendix E, Table 7 for a detailed SIC description.

${ }^{50}$ Felbermayr \& Kohler (2004)
} 


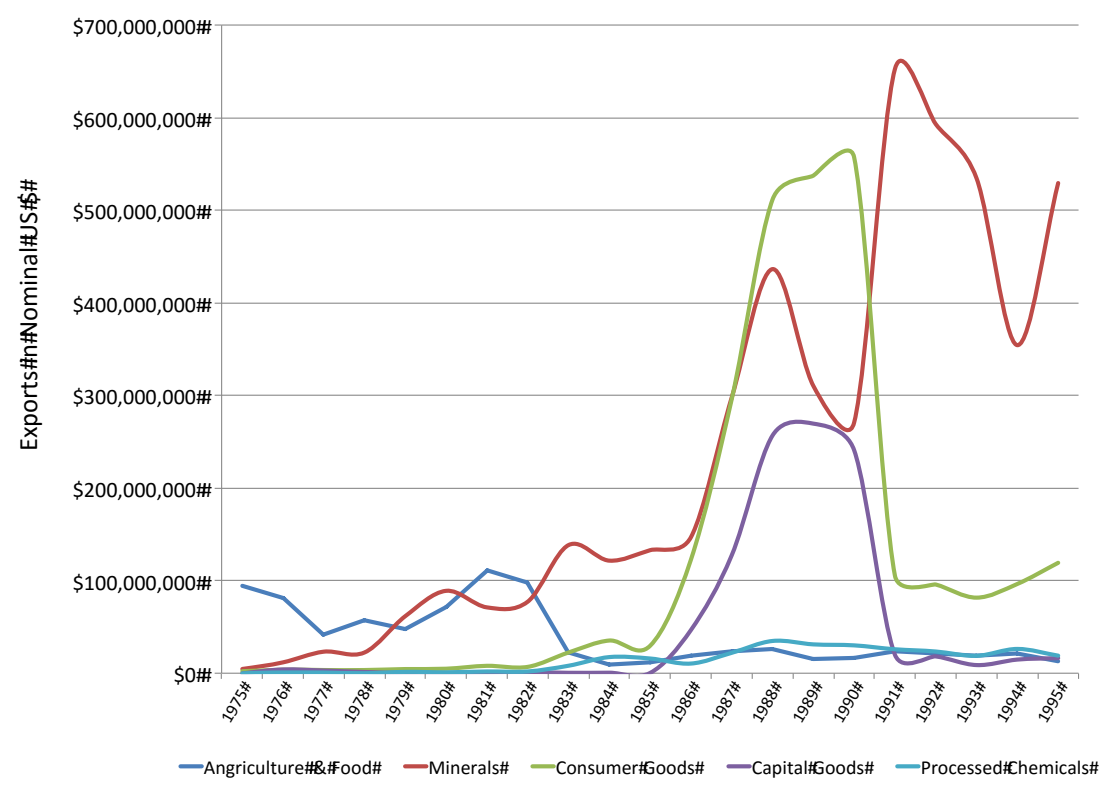

Figure 2: Exports to Taiwan, grouped by SIC codes in five primary categories

Source: Foreign Trade Statistics 1975 - 1985, Department of Trade and Industry, Garner (1994), IMD direction of trade statistics (1986 -1990). South African Revenue Services (1991 - 1995).

Taiwan, prior to 1975 , had traditionally traded minerals and agricultural products in a limited quantity. We thus observe the expansion of these export products along an extensive margin in the trade data. However, there are sizeable shifts in the demand for mineral exports in the periods identified above. This may suggest that other factors could account for these shifts such as "sanction busting" 51 or re-exporting ${ }^{52}$ of resources via Taiwan. Although Taiwanese exports of minerals only represented a small percentage of total exports, the shift is sizeable. This can also be seen in conjunction with changes to Hong Kong exports of minerals, which could therefore support a reorientation towards Asian exports via Taiwan during sanctions.

The second trend is a very pronounced growth in Consumer Goods ${ }^{53}$, and finally the

\footnotetext{
${ }^{51}$ Naylor (1999) explains how various schemes to skirt South African embargoes were deployed by strategic allies.

${ }^{52}$ Geldenhuys (1991, p. 353)

${ }^{53}$ Consumer SIC Grouping: 7, 8, 9, 11, 12 \& 13 - See Appendix E, Table 7 for a detailed description.
} 
increase in Capital Goods, bounded between the sanction years of 1985 and $1991 .{ }^{54}$ Felbermayr and Kohler (2004) notes that when a new trade partnership is newly formed, growth in the diversity and value of exports may accompany the newly established relationship. It is the growth in this diversification of trade (i.e. differentiated Consumer Goods and Capital Goods, as opposed to reference priced Minerals sold on organised markets) that is of particular interest. As Figure 2 clearly demonstrates, South Africa had very little diversified Consumer or Capital Goods exports to Taiwan prior to 1980 . Interestingly, coinciding with sanctions, only after the migration of the Taiwanese to the RIDP zones in the 1980s, growth in these industries are observed in the trade data.

\subsection{Trade diversification}

To quantify this second (extensive) impact I have grouped exports into two categories by matching each Harmonised Commodity Description and Coding System to a product category: (1) differentiated goods and (2) reference-price, homogenous goods. ${ }^{55}$

For the purpose of this study, I will focus on the export side of the balance of trade as it is the diversification from homogenous to heterogeneous that is of particular interest. ${ }^{56}$ The percentage increases in export trade is also reported against OECD ties. These are included to provide a baseline against which the growth in a small Taiwanese population can be compared, and are not intended to be causal. A reference price is defined as a price that is quoted without mentioning a brand name or other producer identification. The reason to distinguish between differentiated goods and homogenous goods is that commodities, traded on organised exchanges, behave differently from differentiated goods. Commodities possess reference prices in which traders can see the price differential between two countries' markets. However, differentiated goods carry no reference price and therefore may hold an information premium conveyed by the possible existence of Taiwanese production networks in South Africa. Because of South Africa's different economic, cultural and political environment, this information premium is expected to be more advantageous for differentiated products, and we may then find a positive effect for trade in differentiated goods between RSA and ROC. It is in such a case, that the Taiwanese migrants could have engaged in a market creation for their RIDP factory production, accounting for this growth.

These baseline results in Table 3 highlight the extent to which most of South African

\footnotetext{
${ }^{54}$ Capital SIC Grouping: 17, 18, 19, 22 \& 23 - See Appendix E, Table 7 for a detailed description.

${ }^{55}$ According to the Rauch \& Trindade (2002) classification of homogenous to heterogeneous exports.

56 This is detailed in the Discussion Section 5.
} 
differentiated trade (43.7\%) in 1975 was dominated by its former OECD trade and investment partners. However, if jewellery and precious stones are removed from the differentiated data, this falls to $31 \%$ in 1975 and $19 \%$ in $1990 .{ }^{57}$

Table 3: Heterogeneous and Homogenous Exports for Taiwan and to the traditional OECD trading links (UK, US, Germany, Japan and France)

\begin{tabular}{|c|c|c|c|c|}
\hline \multicolumn{5}{|c|}{ PERCENTAGEJEXPORTJTRADE)) } \\
\hline$!$ & $!$ & $\begin{array}{l}\text { \%!Population!in! } \\
\text { South!Africa! }\end{array}$ & $\begin{array}{c}\text { Homogenous! } \\
\text { Products! }\end{array}$ & $\begin{array}{c}\text { Differentiated! } \\
\text { Products! }\end{array}$ \\
\hline \multirow{2}{*}{$1975 !$} & $\begin{array}{l}\text { Overseas'Chinese' } \\
\text { network'in'SA' }\end{array}$ & $0.01 \% '$ & $1.02 \%^{\prime}$ & $0.60 \%$ \\
\hline & $\begin{array}{l}\text { OECD'Trading' } \\
\text { Countries"' }\end{array}$ & $2.12 \%$ & $10.86 \%$ & $43.7 \%^{\prime}$ \\
\hline \multirow{2}{*}{$1980 !$} & $\begin{array}{l}\text { Overseas'Chinese' } \\
\text { network'in'SA' }\end{array}$ & $0.03 \%$ & $1.06 \%^{\prime}$ & $0.69 \%$ \\
\hline & $\begin{array}{l}\text { OECD'Trading' } \\
\text { Countries"' }\end{array}$ & $1.95 \%$ & $6.43 \%{ }^{\prime}$ & $23.69 \%$ \\
\hline \multirow{2}{*}{$1985 !$} & $\begin{array}{l}\text { Overseas'Chinese' } \\
\text { network'in'SA' }\end{array}$ & $0.8 \%$ & $0.86 \%$ & $0.90 \% '$ \\
\hline & $\begin{array}{l}\text { OECD'Trading' } \\
\text { Countries"' }\end{array}$ & $1.96 \%$ & $5.49 \% '$ & $17.5 \%$ \\
\hline \multirow{2}{*}{$1990 !$} & $\begin{array}{l}\text { Overseas'Chinese' } \\
\text { network'in'SA' }\end{array}$ & $0.9 \%$ & $2.93 \% '$ & $4.93 \%$ \\
\hline & $\begin{array}{l}\text { OECD'Trading' } \\
\text { Countries'"' }\end{array}$ & $1.82 \%$ & $7.4 \%$ & $24.98 \%$ \\
\hline \multirow{2}{*}{$1995 !$} & $\begin{array}{l}\text { Overseas'Chinese' } \\
\text { network'in'SA' }\end{array}$ & $1.2 \%$ & $3.75 \%$ & $5.93 \%$ \\
\hline & $\begin{array}{l}\text { OECD'Trading' } \\
\text { Countries"' }\end{array}$ & $1.68 \%$ & $5.98 \% "$ & $26.38 \% "$ \\
\hline
\end{tabular}

Note: Gold is excluded from homogenous commodities as exports were highly sensitive to changes in the price and were stockpiled, skewing the analysis.

Source: Foreign Trade Statistics 1975 - 1985, Department of Trade and Industry, Garner (1994), IMF direction of trade (1986 -1990). South African Revenue Services (1991 - 1995).

In 1975, Taiwan received $1.6 \%$ of South Africa's total exports, of which $1 \%$ were reference-price homogenous goods, such as coal and maize. While $0.6 \%$ was considered differentiated, of which approximately $50 \%$ were waxes and edible oils, and $20 \%$ were beverages or spirits. Given that South Africa had both a large agricultural, wine and spirit sector, we would expect this to have dominated early differentiated exports to Taiwan, which did not enjoy the same endowments. However the extent to which these could be considered 'information-intensive' and therefore preference sensitive is debatable as wines or waxes could easily be

${ }^{57}$ This provides for a more conservative estimate of trade and was not removed or differentiated by Edwards \& Lawrence (2008), and is therefore a weakness of their study. 
substituted. If we move further through the time period, the trade patterns changed in favour of Taiwanese information-intensive exports such as electronics, textiles, footwear and specialist chemicals. Moreover, of particular significance is how differentiated trade in traditional markets rapidly declined in the intervening years of sanction (1980 - 1985). However, a key finding from the new data shows that during this tumultuous timeframe, the share of total differentiated products in South Africa's exports escalated from $0.9 \%$ to $4.93 \%$ in favour of Taiwan. ${ }^{58}$

Although small in total differentiated exports, this shift is a noticeable increase. Geldenhuys (1991) notes how by 1984, non-traditional market diversification accounted for roughly a third of South African exports. After 1985, Taiwan appears to outstrip the growth of all other partners, "which can hardly be coincidence that several of the countries have also, to varying degrees experienced international ostracism." 59

A further explanation for this change could have been sanction busting, encouraged by the complementary nature of the South Africa and East Asian economies. Taiwan and to some extent Hong Kong were becoming re-exporters, through which other Asian nations were receiving both differentiated and homogenous South African exports. Pickles and Woods (1989) mentioned that Taiwan could be "a possible conduit for South African exports in the event of comprehensive sanctions." ${ }^{60}$ While Garner (1994) had suggested that during these years, the risk of doing business in South Africa outweighed the benefits of accessing the most industrialised African country. Taiwanese trade may have been a conduit through which countries like Japan accessed their supply chains located in South Africa. This may have particular reference to the automotive sector in which Toyota, GM and Ford had heavily invested in both South Africa and Taiwan. The coming sections will discuss the formation of supply-chain linkages further.

\section{$5 \quad$ Trade and migration}

South-east Asia has strong ethnic business networks as part of their embedded social capital. The links between those in East and South-east Asia have been discussed extensively in the literature, with most attention being given to the Chinese business networks that knit together the export manufacturing success stories in Taiwan, Hong Kong, Singapore, and parts of South-east Asia. ${ }^{61}$ Therefore, within an integrated RIDP production network, co-ethnic Taiwanese suppliers and exporters could be

\footnotetext{
${ }^{58}$ Traditional markets were UK, US, Germany \& France.

${ }^{59}$ Geldenhuys (1991, p. 353)

${ }^{60}$ Pickles \& Woods (1989, p. 512)

${ }^{61}$ Weidenbaum \& Hughes (1996)
} 
regarded as part of a broader diaspora's social capital embedded in South Africa. Recent scholarship has examined how these networks have also spread from Asia ${ }^{62}$ to Europe, ${ }^{63}$ the $\mathrm{US}^{64}$ and now into Africa. ${ }^{65}$

Kotkin (1993) stated that "Chinese entrepreneurs remain in essence, arbitrageurs, their widespread dispersion a critical means of identifying prime business opportunities." 66 The South African hypothesis is therefore neatly summarised by Weidenbaum and Hughes (1996) who noted that;

"The members of the bamboo network operate in the interstices of the trading world. They make components, manufacture for others, and perform sub-assembly work. They are also heavily involved in wholesaling, financing, sourcing, and transporting. The leading businessmen know each other personally and do deals together, with information spreading through an informal network rather than through more conventional channels" 67

I have further disaggregated the export industries into industrial sectors in which Taiwanese entrepreneurs were heavily invested, exploring how Taiwanese investors contributed to growth of differentiated exports. Of particular interest to this paper is the way that networks affect the relationship between migration and trade when the two countries have been internationally isolated. With a further variable, namely an annual reconstruction of Taiwanese migration to the homeland RIDP zones, I will also examine qualitative archival accounts, questioning to what extent these migrant investors, "using their vast trading networks", 68 were able to diversify export trade from South Africa to Taiwan.

Migrants can provide an information bridge between two dense networks: in this case, suppliers in South Africa and customers' demands in established export markets such as Taiwan, Asia or Europe. Taiwanese migrants possessed economic, cultural and institutional knowledge about both the home (Asian) and the host markets (Southern Africa), in which they were able to mediate exchange, thus increasing trade above what it would be in the absence of their migration. Although these two nations may have been a special case, it could be argued that without migration neither would have traded to a greater degree.

\footnotetext{
${ }^{62}$ Rauch \& Trindade (2002)

${ }^{63}$ Hsu \& Saxenian (2000)

${ }^{64} \mathrm{Head}, \mathrm{Ries} \&$ Swenson (1995)

${ }^{65}$ Bräutigam (2003)

${ }^{66}$ Kotkin $(1993$, p. 17)

${ }^{67}$ Weidenbaum \& Hughes (1996, p. 198)

${ }^{68}$ Minister K.T. Li, 1980 newspaper article in the New China Times (01/03/1980).
} 
Seminal work from Gould (1994) demonstrates how immigrants' associations to their home country were able to foster bilateral trade linkages. These ties include knowledge of home-country markets, language, preferences, and business contacts that have the potential to decrease trading transaction costs, and increase market knowledge. This is evident in the archival accounts discussed below (5.2). The networks themselves are woven together with strands of information, shared contacts, sometimes finance (credit or investment), and a degree of trust, frequently backed up by group-based sanctions. If we conceptualise Taiwanese entrepreneurship in South Africa as "embedded in networks of continuing social relations" ${ }^{\prime 9}$ then social capital and networks are a central tenet in how bilateral trade expanded. The benefits derived from belonging to an ethnic-specific group and having social ties via former employment or managerial posts facilitated trade.

South Africa was in upheaval in the 1980s. Institutionalised racism precluded migrant Taiwanese from credit markets or domestic supply chains, while sanctions prevented access to large export markets in Europe or North America. Greif (1994) and Dunlevy (2006) demonstrate how private order networks substitute for weakening political institutions. As such early migrants had to form interconnected supply chains in South Africa that were an extension of customers in Taiwan with whom they had a relationship that could transcend the institutionalised apartheid risks.

In 1981 the Taiwanese entrepreneurs in South Africa initiated their first Chamber of Commerce (later the African Taiwanese Chamber of Commerce or ATCC) to facilitate trade and interaction between the communities. Appointing Taiwanese agents in Taipei, the homeland development corporations also facilitated further ROC investment in the RIDP. Hart and Todes (1997) observed that "the predominance of Taiwanese investment in the 1980s was not just a quirk of apartheid subsidies and diplomatic ties between pariah states, but [...] organised around familial and network forms of production." "70 To explore how industries in which Taiwanese investors contributed to growth of network forms of production." The formation of network migration and investment within the RIDP zones will be discussed next.

\subsection{Changes to Taiwanese exports}

The recurring findings in the literature emphasise how Taiwanese entrepreneurs provided foreign market information to both customers and supply chains in Asia, spurring exports in specific sectors. To explore the possibility of RIDP investors contributing to the growth of differentiated exports, I disaggregate the export

\footnotetext{
${ }^{69}$ Gould (1994, p. 365)

${ }^{70}$ Hart \& Todes (1997, p. 36)
} 
industries into the industrial sectors in which the Taiwanese entrepreneurs operated. Table 4 below summarises the percentage investment in each manufacturing sector during the RIDP zones between 1978 - 1992. Although any growth in exports cannot be directly linked to these investors, I merely seek to observe the possibility of a protrade effect of RIDP investment and exports. The possibility that Taiwanese investors may have developed as part of an integrated supply network will then be discussed in the following section.

Table 4: Percentage Taiwanese Investment in each RIDP Manufacturing Sector (1978 - 1992).

\begin{tabular}{lc}
\hline Manufacturer£ategory+ & $\begin{array}{c}\text { Percentageøffaiwanese+ } \\
\text { Manufacturersperfector+ }\end{array}$ \\
\hline Electrical"' & $11.5 \% "$ \\
Plastics"and"Allied'Chemicals" & $17.7 \% "$ \\
Clothing"and"Knitwear" & $34 \% "$ \\
Raw"Textiles" & $1.85 \% "$ \\
Footwear" & $9.62 \% "$ \\
Packaging" & $8.9 \% "$ \\
Metal"ware" & $5.5 \% "$ \\
Furniture" & $1.1 \% "$ \\
Jewellery" & $2.59 \% "$ \\
Cosmetics"and"Toys" & $1.1 \% "$ \\
Food" & $1.1 \% "$ \\
Other" & $4.81 \% "$ \\
\hline
\end{tabular}

Source: Board for the Decentralisation of Industry. National Archive, Pretoria, South Africa. sample as they skew the results due to the high value but low volume

Examining the sectors in which the Taiwanese invested and the export growth of differentiated goods is particularly enlightening. For example $10 \%$ of the Taiwanese entrepreneurs were invested in clothing and knitwear industries. While in 1975, South Africa exported almost none of these products (0.03\%), by 1990, $17.45 \%$ of the exports were from this sector. The same is observed in transport equipment (1.6 $\%$ in 1975) as Taiwanese firms in the RIDP zones started producing OEM equipment for vehicle manufacturers. Appendix F, Table 5 details all sectors and exports to Taiwan over the period. Given the possible implication of Taiwanese migration to South Africa measured in the bilateral trade data, the next section will discuss to what extent qualitative accounts provide additional evidence for the observed shift in trade. 


\section{2}

Taiwanese networks in South Africa

After the 1975 and 1978 bilateral investment and trade treaty (BITTs), the Taiwanese community were racially recognised as honorary whites, and offered the necessary private property protection under the law. The BITTs may have created "ethnic tolerance in which the Chinese could emerge in South Africa as a legitimate business group, free from official prejudice, protected by trade agreement, but they were suffused in social exclusion." ${ }^{71}$ As such, this legal recognition did not extend to any social or commercial inclusion in the homelands or urban centres like those in Malaysia or Hong Kong, with large Chinese populations and Taiwanese investment.

These entrepreneurs found themselves precluded from business affiliations or social linkages with white South Africans who dominated manufacturing and the business communities. Furthermore, due to the deep racial divisions, entrenched by the apartheid laws, both Chinese South Africans and Taiwanese migrants were excluded from many of the formal manufacturing and business organisations, and prohibited from formal credit markets. Lawrence Ting an early investor noted that:

"The industrialists initially had problems with raising finance as they were not known to the South African banks, and by providing capital themselves were at the mercy of South Africa's exchange-control regulations. "72

While Charles Liao, secretary of the Taiwanese Chamber of Commerce explained how the BITTs offered little protection:

"[...] too many promises had been made to Chinese investors, and the governments of Taiwan and South Africa could have offered industrialists more support which meant we had to group together and find solutions". ${ }^{73}$

This was further compounded by language and cultural divides not only between the Taiwanese and South Africans, but also between the Chinese South Africans who in the main originated from Cantonese-speaking areas. ${ }^{74}$ Migrants to the homelands

\footnotetext{
${ }^{71}$ Sono \& South African Institute of Race Relations (1999, p. 36)

72 Yap (1996, p. 421)

${ }^{73}$ Liao C (1991), Biennial conference speech at the Chinese Association on the "The Chinese investor in Southern Africa in retrospect and futurity".

74 Park (2010) notes that the early ancestors of today's Chinese South Africans, were two distinct ethnic/language groups: the Cantonese and the Hakka (or Moiyeanese), both from Guangdong Province. These two groups settled in different parts of South Africa , and did not mingle until well into the apartheid period when their small numbers and apartheid laws essentially forced them to coexist. South African Chinese did not
} 
struggled to speak English, but had to contend with the rural settings of the RIDP zones where Africans also spoke little English. Charles Liao summarised the early cultural and operational challenges for new migrants in the 1970s:

"From a densely populated Taiwan to the rural underdeveloped countryside of the border areas, the new settlers found themselves isolated, far from city amenities, without a place of worship and unable to purchase Chinese provisions [...] Insufficient research on their part often led to the establishment of factories producing goods for which there was no market in South Africa. "75

Ironically, it appears that the naivety and lack of domestic market knowledge resulted in even greater stimulus to export their manufactured goods. The early excess production supply, especially of textiles, could not be sold into South Africa or Africa. As such, Taiwanese factories had to export their products back to warehouses in Asia. ${ }^{76}$ The formation of export supply chains became the base for exports as both sanctions and knowledge of customer preference in Taiwan, Hong Kong and Japan provided an easier route to market. This began to change as they quickly adapted, or new entrepreneurs joined the production network allowing for economies of scale producing higher-value finished goods. The KwaZulu Finance Corporation noted in their annual reports that many of the later entrants (after 1983) came to affiliate in domestic production networks:

"The early Taiwanese migrants who had come to the country and our development zones had to rely on their existing home-market business relationships to export goods. Now that hundreds more have followed, we see greater volumes of finished goods being exported to markets, mostly in Asia, but also Europe and our African neighbours. The Taiwanese export not only their products, but customer loyalty as orders can be guaranteed from long-standing relationships established when the island was still referred to as Formosa. "77

In later research Hart (1996) also found that the Taiwanese industrialists in Newcastle, a small town in KwaZulu, had to rely on their existing co-ethnic business networks, using it as an extension of factories operating in Asia. The Taiwanese immigrants leveraged their home country (ROC) links but also links to Hong Kong, which in turn provided export markets and enhanced bilateral trade flows between

\footnotetext{
identify at all with the Taiwanese and felt that they had given the Chinese a bad name.

${ }^{75}$ Van der Watt \& Visser (2008, p. 122)

${ }^{76}$ Yap (1996, p. 475)

${ }^{77}$ KwaZulu Finance Corporation, trade publication (1985).
} 
Asia and Southern Africa. This sentiment was echoed in the minutes of the KFC annual reports, which noted how:

"Taiwanese migrants reduced both the cost and risk associated with immigrating to KwaZulu, increasing the net returns, and thus the probability of more migrating to our industrial zones in Newcastle, and Indizini. They bring not only production knowledge and capital, but customer knowledge and their loyalty. "78

\section{Conclusion}

With the 1975 signing of a trade deal, ethnic Chinese were officially recognised, following a diplomatic pivot towards Taiwan. This intensified period of investment, migration and bilateral trade would later develop into a large diaspora of Asian manufacturing firms on the African continent. ${ }^{79}$ Neither country had any formal diplomatic agreement a mere 10 years prior to this meeting. Yet in a few short years, they came to depend diplomatically on one another. But more importantly, as I have shown, they also became more economically engaged as migration grew. During sanctions, a clearly observable increase in export trade to Taiwan is measured in the new trade data assembled above.

Prior to 1975 South Africa mostly traded with former western and OECD trade partners ( $73 \%$ in 1975). However, the quantum of bilateral trade (and migration) after 1975 was classified or omitted by government agencies as a response to UN sanctions and punitive disinvestment by foreign firms. Relying on estimates, prior research has noted the methodological problems in assessing trade flows as a result of a data embargo, and doubted the accuracy of any publicly available trade statistics during sanctions. Assembling a new data series from declassified trade statistics demonstrates that the inflow of foreign investment and immigrants from Taiwan may have increased the potential for manufactured exports. Moreover, by disaggregating the extensive and intensive margin of trade, it is shown how South Africa not only increased its trade volume, but more importantly, increased the diversity of exports to Taiwan. When official bilateral trade data was once again published in 1994, Taiwan's trade with South Africa was more diversified, and in some manufacturing sectors exceeded that of its former OECD trade partners. These findings offer a novel perspective on the rise of export manufacturing, and shows how migration to a small open economy such as South Africa could have a positive impact on trade.

\footnotetext{
${ }^{78}$ KwaZulu Finance Corporation (1988) annual report, Government Publications, University of Cape Town

${ }^{79}$ Although Chinese firms have begun investing directly in African countries, no evidence as measured by number of firms or total country employment suggests that the quantity or diversity has reached that of Taiwanese manufacturing firms in South Africa between 1975 and 1996.
} 
Exploring the possibility of Taiwanese entrepreneurs in the RIDP zones increasing exports of differentiated goods in specific sectors demonstrated that both investments and exports increased in tandem. Although not causal, this suggests that Taiwanese entrepreneurs, who invested in these sectors were able to leverage their business links, possibly via a migrant network and therefore increase trade. This form of protrade migration is indicative of the network effects suggested by the existing economic geography literature. Similarly the existing trade literature found a greater pro-trade effect for differentiated products amongst ethnic networks. This suggests that Taiwanese migrant operated by providing market information across international borders about export opportunities.

Taiwanese ethnic networks provided a deterrent against opportunistic behaviour through enforcement of community sanctions. Taiwanese entrepreneurs were outsiders in the South African RIDP zones. Although nominally protected by the trade treaties (BITT's), institutionalised racism precluded them from engaging in formal credit or domestic networks. Moreover, given the unstable institutional environment in South Africa, they operated in a close business community forming the "Taiwanese Chamber of Commerce in Africa" thus encouraging further cooperation.

As such, it is possible that network linkages were helping to overcome the informal barriers to trade imposed by the racial isolation and increasing risk of operating in South Africa during a state of emergency. Taiwanese entrepreneurs could use their co-ethnic linkages to cooperate by sharing market knowledge or credit. This promoted an increase in exports to Taiwan, not only by signalling home market preferences, but also by providing community enforcement that deterred violations of contracts in a weak legal environment. For example, Weidenbaum and Hughes (1996) noted how in Asia "if a business owner violates an agreement, he is blacklisted. This is far worse than being sued, because the entire Chinese network will refrain from doing business with the guilty party". ${ }^{80}$ Similarly in South Africa, Hart (2002a) found that some of the older Taiwanese firms in KwaZulu Natal supplied credit to the new firms. This would suggest a high level of trust amongst the network of suppliers and contractors in the RIDP zones. Migrant networks not only facilitated the initial migration decision but also acted as a force for perpetuating migration. It became easier for potential Taiwanese enterprisers to move given the manufacturing complex in which they were embedded and the trust that existed in their network. The new factories, with established links in the migrant network, then perpetuated an ongoing cycle linking potential buyers and markets through networks.

\footnotetext{
${ }^{80}$ Weidenbaum \& Hughes (1996, p. 36)
} 


\section{References}

Bräutigam, D. 2003. 'Close encounters: Chinese business networks as industrial catalysts in SubSaharan Africa', African Affairs, 102(408), 447-467.

Dietz, J.L. 1992. 'Overcoming underdevelopment: What has been learned from the East Asian and Latin American experiences?', Journal of Economic Issues, 26(2), 373-383.

Dunlevy, J. 2006. 'The influence of corruption and language on the protrade effect of immigrants: Evidence from the American States', The Review of Economics and Statistics, 88(1), 182-186.

Edwards, L. \& Lawrence, R. 2008. 'South African trade policy matters: Trade performance and trade policy', Economics of Transition, 16(4): 585-608.

Feinstein, C.H. 2005. An economic history of South Africa: conquest, discrimination and development. The Ellen McArthur lectures. Cambridge, New York: Cambridge University Press.

Felbermayr, G.J. \& Kohler, W. 2004. Exploring the intensive and extensive margins of world trade. CESifo Group Munich CESifo Working Paper Series 1276.

Garner, J.F. 1994. South Africa's trade partners, 1986-1991. London: London: London School of Economics and Political Science/Centre for the Study of the South African Economy and International Finance.

Geldenhuys, D. 1991. Isolated states: A comparative analysis. Cambridge studies in international relations. Cambridge, Cambridge University Press.

Gould, D.M. 1994. Immigrant links to the home country: Empirical implications for U.S. bilateral trade flows', The Review of Economics and Statistics, 76(2), 302-316.

Greif, A. 1994. 'On the political foundations of the late medieval commercial revolution: Genoa during the twelfth and thirteenth centuries', The Journal of Economic History, 54(2), 271-287.

Grimm, S., Kim, J., Anthony, R., Attwell, R. \& Xiao, X. 2014. South African relations with China and Taiwan economic realism and the 'one china' doctrine. Centre of Chinese Studies, Stellenbosch University.

Gutiérrez de Piñeres, S.A. \& Ferrantino, M. 1997. 'Export diversification and structural dynamics in the growth process: The case of Chile', Journal of development Economics, 52(2), 375-391.

Hanlon, J. \& Omond, R. 1987. The sanctions handbook : For or against? Harmondsworth: Penguin Books. Joseph Hanlon and Roger Omond.

Hart, G. 1996. Global connections: The rise and fall of a Taiwanese production network on the South African periphery. University of California, Institute of International Studies, Berkeley, CA, Working Paper No. 6. 
Hart, G. 2002a. Disabling globalization: places of power in post-apartheid South Africa. Berkeley: University of California Press.

Hart, G. 2002b. Reworking apartheid legacies: Global competition, gender and social wages in South Africa, 1980 - 2000. Social policy and development programme paper, Geneva: United Nations Research Institute for Social Development.

Hart, G. \& Todes, A. 1997. 'Industrial decentralisation revisited', Transformations, 31-53.

Havemann, R. 2014. 'The exchange control system under apartheid', Economic History of Developing Regions, 29(2), 268-286.

Head, C.K., Ries, J.C. \& Swenson, D.L. 1995. 'Agglomeration benefits and location choice: Evidence from Japanese manufacturing investments in the United States', Journal of International Economics, 38(3-4): 223-247.

Hsu, J.Y. \& Saxenian, A. 2000. 'The limits of Guanxi capitalism: Transnational collaboration between Taiwan and the USA', Environment and Planning A, 32(11), 1991-2005.

Jones, S. \& Inggs, J. 1994. The South African economy in the 1980s. South African journal of economic history, London: Economic History Society of Southern Africa.

Jones, S. 2002. The decline of the South African economy. Northampton, MA: Edward Elgar Publishing.

Kaempfer, W., Lehman, J. \& Lowenberg, A. 1987. 'Divestment, investment sanctions, and disinvestment: An evaluation of anti-apartheid policy instruments', International Organization, 41(3), 457-473.

Kotkin, J. 1993. Tribes: How race, religion, and identity determine success in the new global economy. London and New York: Random House.

MacDonald, J. \& MacDonald, L. 1964. 'Chain migration ethnic neighbourhood formation and social networks', The Milbank Memorial Fund Quarterly, 42(1), 82-97.

Moll, T. 1991. 'Did the apartheid economy 'fail'?', Journal of Southern African Studies, 17(2), 271-291.

Naylor, R.T. 1999. Economic warfare: Sanctions, embargo busting, and their human cost. Chicago and London: Northeastern University Press.

Ovendon, K. \& Cole, T. 1989. Apartheid and international finance: A programme for change. Northampton, MA: Penguin Books.

Park, Y.J. 2008. 'White, honorary white, or non-white: Apartheid era constructions of Chinese', Afro-Hispanic Review, 27(1), 123-138. 
Park, Y.J. 2010. 'Boundaries, borders and borderland constructions: Chinese in contemporary South Africa and the region', African Studies, 69(3), 457-479.

Pickles, J. \& Woods, J. 1989. 'Taiwanese investment in South Africa', African Affairs, 88(353), 507-528.

Rauch, J. \& Trindade, V. 2002. 'Ethnic Chinese networks in international trade', Review of Economics and Statistics, 84(1), 116-130.

Rauch, J.E. \& Casella, A. 2001. Networks and markets. New York, N.Y.: Russell Sage.

Reis, J.G. \& Farole, T. 2012. Trade competitiveness diagnostic toolkit. Washington, D.C.: World Bank Publications.

Sono, T. \& South African Institute of Race Relations. 1999. Race relations in post-apartheid South Africa. Johannesburg: South African Institute of Race Relations.

Stapleton, C. 2015. The migrant network effect: An empirical analysis of rural-to-urban migration in South Africa." ERSA Working Paper series (No. 504), 1-42.

United Nations Centre against apartheid. 1978. Actions by international non-governmental organizations in the implementation of United Nations resolutions on the problem of apartheid, and assistance provided by them to the oppressed people of South Africa. New York: United Nations.

Van der Watt, L.M. \& Visser, W.P. 2008. 'Made in South Africa': A social history of the Chinese in Bloemfontein, Free State Province, South Africa ca. 1980-2005', Stellenbosch History Journal, 33(1), 121-142.

Vézina, P-L. \& Parsons, C. 2016. 'Migrant networks and trade: The Vietnamese boat people as a natural experiment', Working paper and $R \& R$ at the Economics Journal, 1(1), 1-43.

Weidenbaum, M. \& Hughes, S. 1996. The bamboo network: How expatriate Chinese entrepreneurs are creating a new economic superpower in Asia. New York: Martin Kessler Books.

Yap, M. 1996. Colour, confusion and concessions: the history of the Chinese in South Africa. Hong Kong: Hong Kong University Press. 


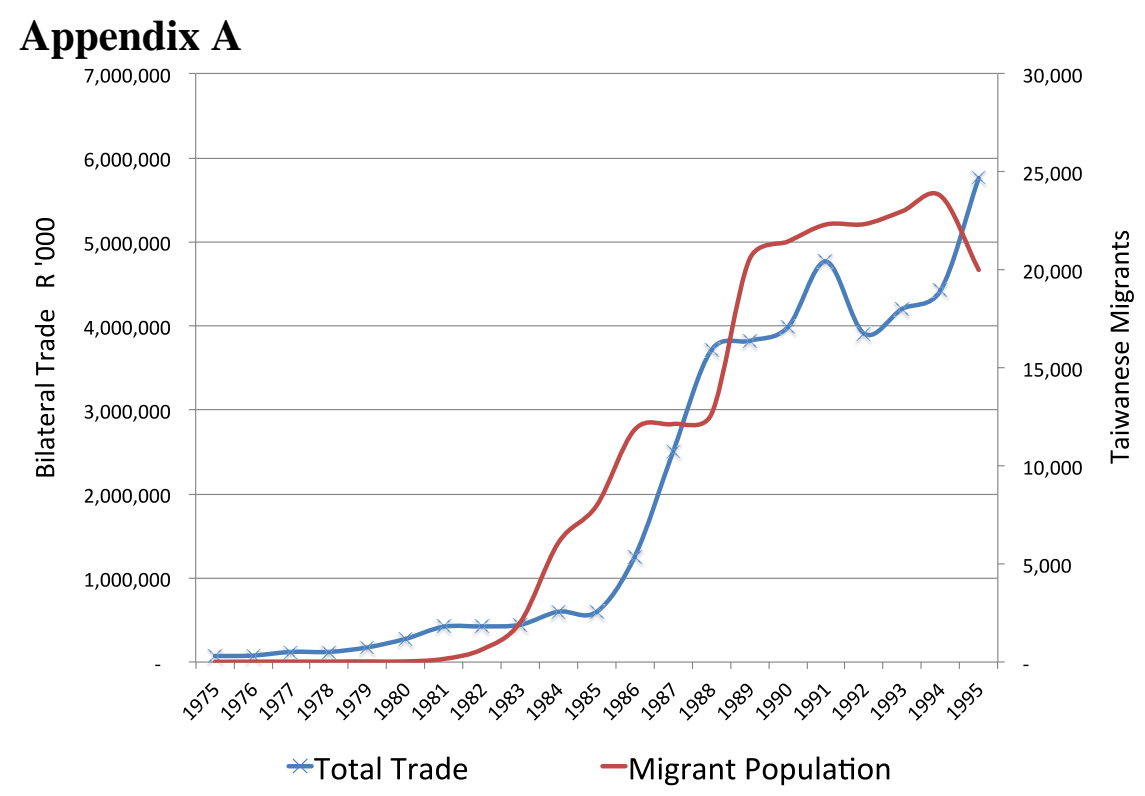

Figure 3: Plots the growth of bilateral trade and migration between South Africa and Taiwan (1975 - 1995)

Source: Estimates of Taiwanese migration and population series assembled from the Board for the Decentralisation, business license applications (National Archive, Pretoria, RSA). Bilateral trade is assembled from the South African Revenue Service (1975 - 1985), National Treasury (1986 - 1992), and the South African Revenue service (1993 - 1995). 


\section{Appendix B}

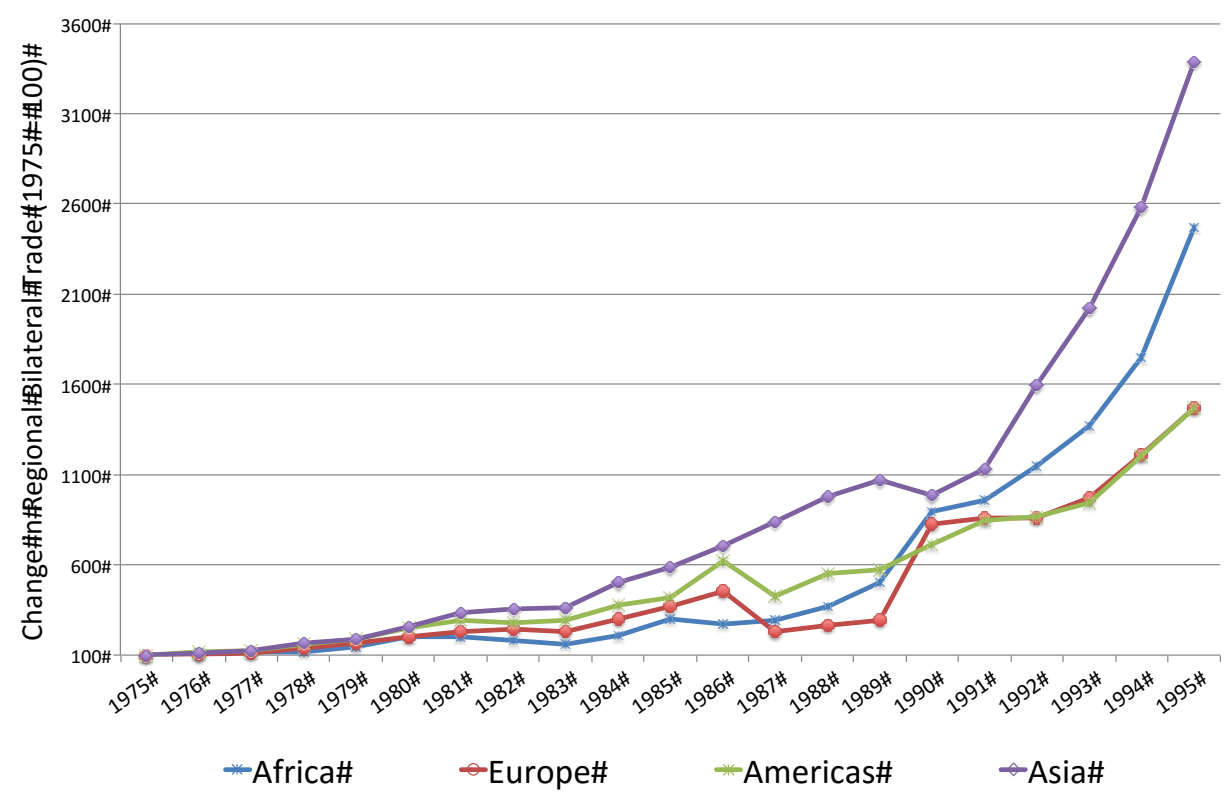

Figure 4: Change in Regional Bilateral Trade (1975 based to 100)

Source: Trade series assembled from Foreign Trade Statistics 1975 - 1985, with supplementary statistics from the Department of Trade and Industry, Garner (1994) and IMD direction of trade statistics (1986 -1990). South African Revenue Services using HS codes provided the years $1991-1995$. 


\section{Appendix C}

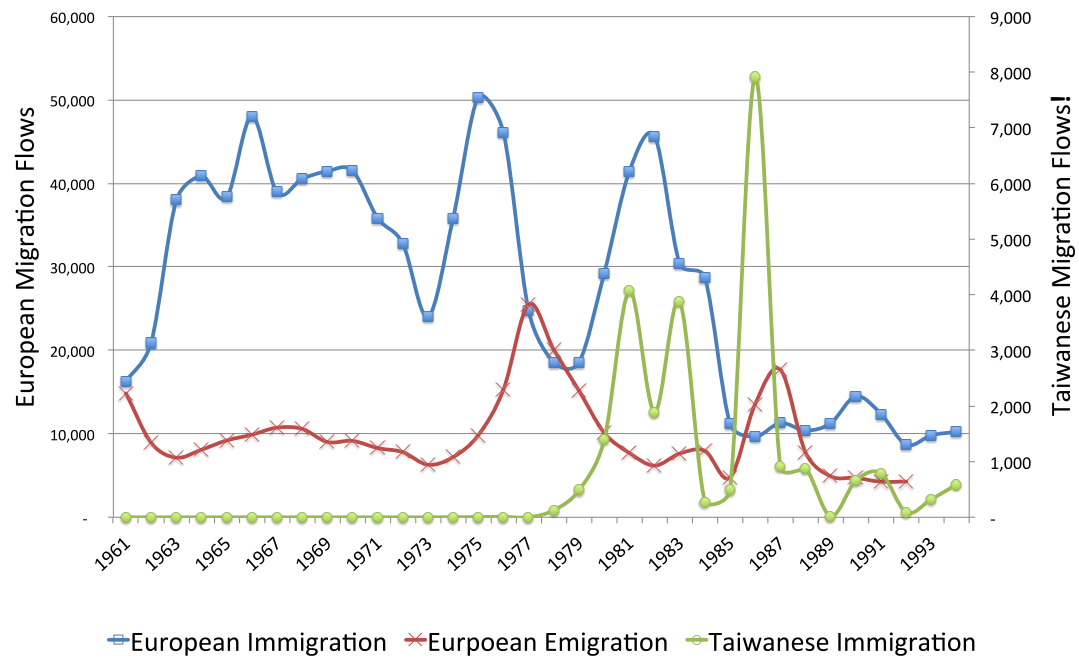

Figure 5: European and Taiwanese Migration between 1961 and 1994

Source: European - Department of Internal Affairs, Annual Reports, The National Archive, Pretoria, and The Government Publications Library, University of Cape Town (European: Germany, France and US). Taiwanese Migration and population series assembled from the Board for the Decentralisation, business license applications (National Archive, Pretoria, RSA). 


\section{Appendix D}

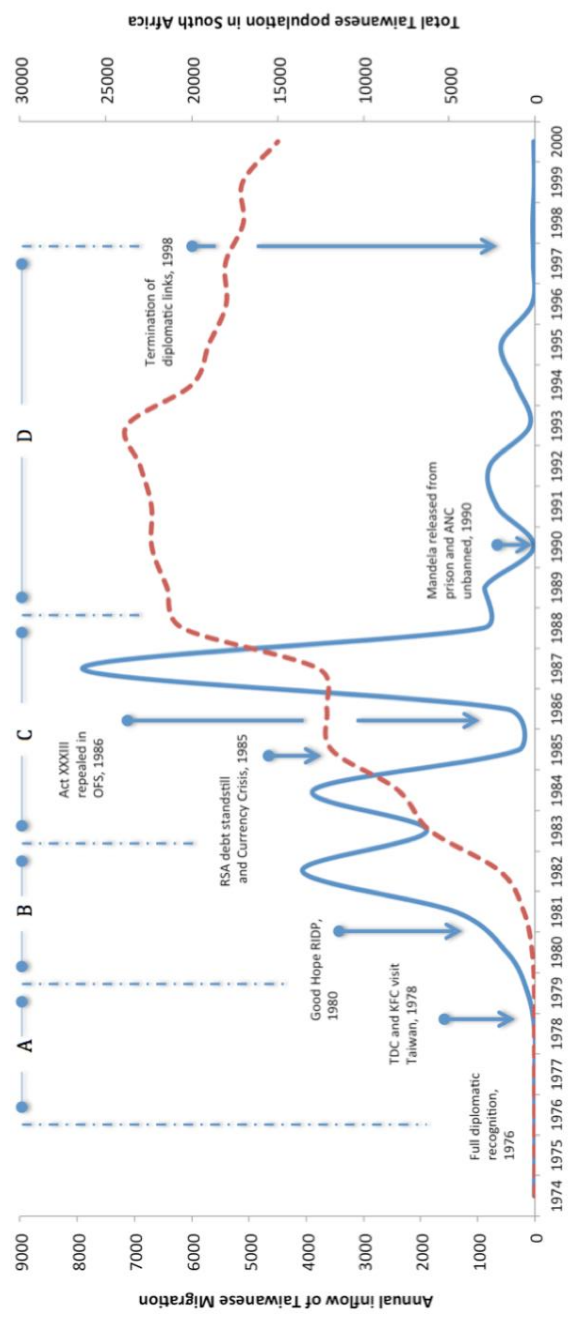

Figure 6: Taiwanese annual migration and total population (broken line) between 1974 and 2000

Source: Estimates of Taiwanese migration and population series assembled from the Board for the Decentralisation, business license applications (National Archive, Pretoria, RSA). 


\section{Appendix E}

\begin{tabular}{|c|c|c|c|}
\hline " & \multicolumn{3}{|c|}{ SECTIONSCOF(THE(HARMONISED(SYSTEMC } \\
\hline Section( & Ref(Price( & Chapter| & Description( \\
\hline IC & YESC & 1 (to)(5) & Live"animals,"animal"products." \\
\hline IIC & YESC & 6fto(14) & Vegetable"products." \\
\hline IIIC & No( & 15( & $\begin{array}{l}\text { Animal"or"vegetable"fats"and"oils"and'their"cleavage"products;" } \\
\text { prepared"edible'fats;"animal"or"vegetable"waxes." }\end{array}$ \\
\hline IVC & No( & 16(to 24$)$ & $\begin{array}{l}\text { Prepared'foodstuffs, 'beverages,"spirits,"and"vinegar;"tobacco"and" } \\
\text { manufactured"tobacco"substitutes." }\end{array}$ \\
\hline $\mathrm{Vc}$ & YESC & 25(tor27) & Mineral"products." \\
\hline vic & No( & 28tto 38 ( & Products"of the"chemicals"or"allied'industries." \\
\hline VIIC & No( & 39 to 401 & Plastics"and"articles'thereof;"rubber"and"articles'thereof." \\
\hline VIIIC & No( & $i^{41(\operatorname{to} 43 i}$ & $\begin{array}{l}\text { Raw"hides"and"skins,"leather,'fur"skins"and"articles"thereof;"saddler" } \\
\text { and"harness,"travel"articles,"handbags"and"similar"containers;" } \\
\text { articles"of"animal"gut"(other"than"silkworm!gut)." }\end{array}$ \\
\hline IXC & No( & 44t(to 461 & $\begin{array}{l}\text { Wood"and"articles"of'wood,"wood"charcoal,"cork"and"articles"of"cork,' } \\
\text { manufactures"of"straw,"of"esparto"or"of"other"plaiting"material," } \\
\text { basket"ware"and"wickerwork." }\end{array}$ \\
\hline $\mathbf{x}($ & YESC & ( 47 (to) 499 & $\begin{array}{l}\text { Pulp"of"wood"or"of"other"fibrous"cellulosic"material;"waste"and"scrap } \\
\text { of"paper"or"of"paperboard;"paper"and'paperboard"and"articles" } \\
\text { thereof." }\end{array}$ \\
\hline XIC & No( & 50 to 663( & Textiles"and"textile"articles." \\
\hline XIIC & No( & $i^{64(\operatorname{to} 667 i}$ & $\begin{array}{l}\text { Footwear,"headgear,"umbrellas,"sun"umbrellas,"walking! sticks,"seat! } \\
\text { sticks,"whips,"riding!crops"and"parts'thereof;"prepared'feathers"and" } \\
\text { articles"made'therewith,"artificial"flowers,"articles"of'human"hair." }\end{array}$ \\
\hline XIIIC & No( & 68ttof70) & $\begin{array}{l}\text { Articles"of"stone,"plaster,"cement,"asbestos,"mica"or"similar" } \\
\text { materials,"ceramic"products,"glass"and"glassware." }\end{array}$ \\
\hline XIVC & No( & ( 710 & $\begin{array}{l}\text { Natural"or"cultured"pearls,"precious"or"semi!precious"stones," } \\
\text { precious"metals,"metals"clad"with"precious"metal"and"articles" } \\
\text { thereof;"imitation"jewellery,"coins." }\end{array}$ \\
\hline $\mathrm{xvC}$ & YESC & 72 to $(83)$ & Base"metals"and"articles"of'base"metal." \\
\hline Xvic & NOC & $i_{1}^{84(t o(85 i)}$ & $\begin{array}{l}\text { Machinery"and"mechanical"appliances,"electrical"equipment;"parts" } \\
\text { thereof,"sound"recorders"and'reproducers,"television"image"and" } \\
\text { sound"recorders"and"reproducers,"and"parts"and"accessories"of"such' } \\
\text { articles." }\end{array}$ \\
\hline XVIIC & No( & 86tto(89) & Vehicles,"aircraft,"vessels"and"associated"transport"equipment." \\
\hline ( & No( & 90(tos & $\begin{array}{l}\text { Optical,"photographic,"cinematographic,"measuring,"checking," } \\
\text { precision,"medical"or"surgical"instruments"and"apparatus,"clocks" } \\
\text { and'watches,"musical"instruments;"parts"and"accessories'thereof." }\end{array}$ \\
\hline XIXC & NO( & 94(to 961 & Miscellaneous"manufactured"articles." \\
\hline $\mathrm{xx}($ & No( & 97( & Works"of"art,"collectors'"pieces"and"antiques." \\
\hline XXIC & NO( & JC & Other"unclassified"goods." \\
\hline XXIIC & No( & $\mathrm{JC}$ & Special"classification"provisions:"Original'Equipment"Components" \\
\hline XXIIIC & No( & 98( & $\begin{array}{l}\text { Special"classification"provisions:"Other'Miscellaneous"OEM" } \\
\text { Component" }\end{array}$ \\
\hline
\end{tabular}

Note: Column 2 (Ref Price) denotes whether the SIC category could be considered a reference price good, i.e. undifferentiated commodity and therefore infers no information premium. Goods that possess no information premium are categorised as homogenous and therefore grouped as such. While those that have no reference price, are categorised as a differentiated are therefore subject to an information premium. For the purpose of this analysis, this bivariate categorisation is used to ascertain whether migration increased the trade in information intensive differentiated products.

\section{Figure 7: Sections Of The Standard Industrial Classifications Harmonised System}




\section{Appendix F}

Table 5: SIC Percentage Differentiated Exports to Taiwan (1975 - 1995)

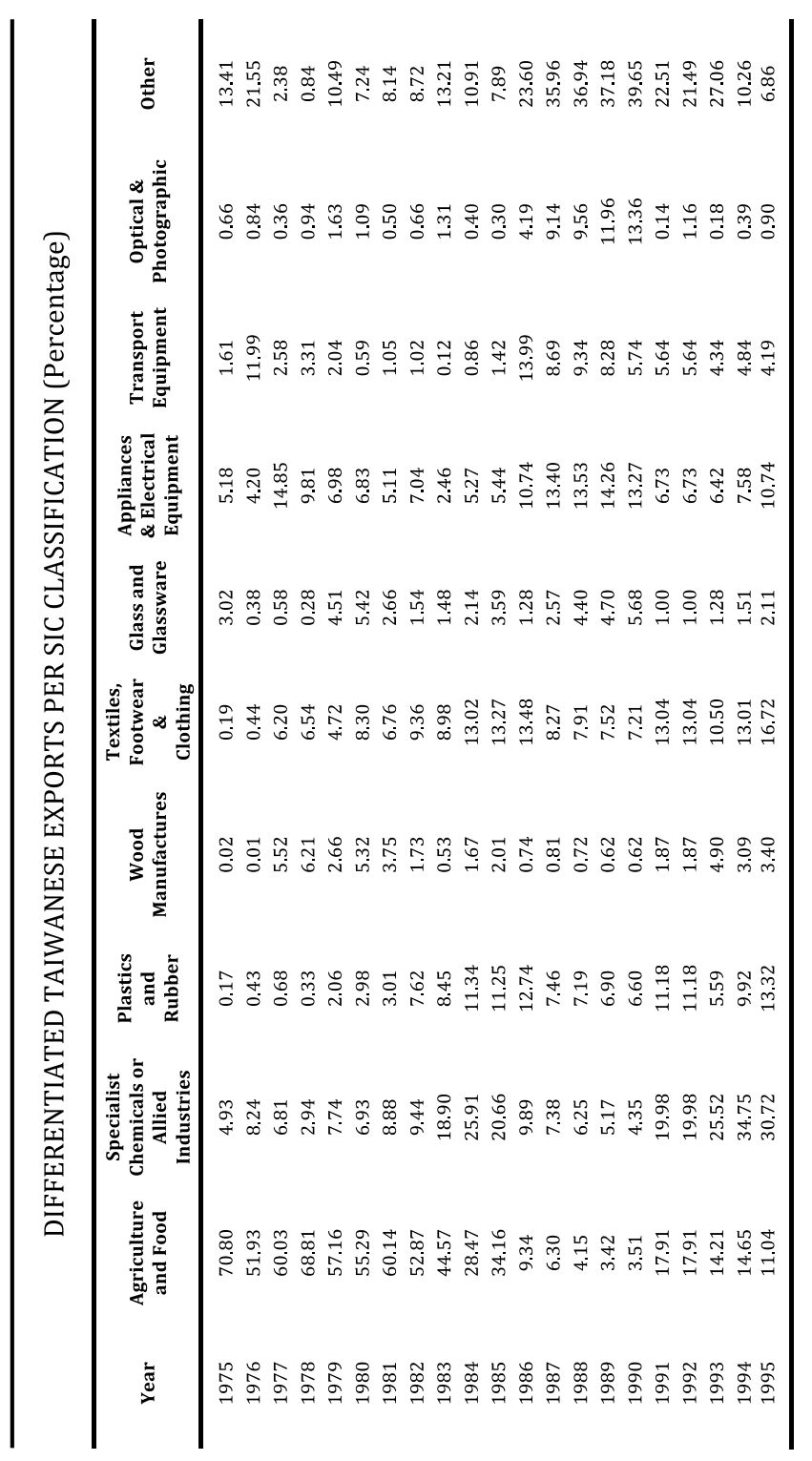

J.STUD.ECON.ECONOMETRICS, 2018, 42(2) 